\title{
Local development initiatives in the Lake Ladoga Region: Reasons for success and approaches to funding*
}

\author{
J. Nikula ${ }^{1}$, I. Kopoteva ${ }^{1,2}$ \\ ${ }^{1}$ University of Helsinki \\ Unioninkatu, 33, Helsinki, 00014, Finland \\ ${ }^{2}$ Russian Presidential Academy of National Economy and Public Administration \\ Vernadskogo Prosp., 82, Moscow, Russia, 119571 \\ (e-mail: jouko.nikula@helsinki.fi; inna.kopoteva@gmail.com)
}

\begin{abstract}
The peripheral (rural) regions in most countries face four vicious circles that contribute to their low level of development and inability to achieve the sustainable level of development. The first vicious circle is related to demography and is caused by the vulnerable population; very few young people and imbalance of women and men lead to poor economy, i.e. dominance of subsistence economy over production or trade; unfavorable age structure combined with poor services lead to very low birth rate and high levels of migration. The second vicious circle of remoteness is related to the fact that poor infrastructure does not attract businesses or new residents in the area, which contributes to high levels of migration as young and working-age population, especially families with young children, move out. The third vicious circle is related to education: the low level of education and skills mean that there is no labor force available in the region, which prevents business from entering the local market. Lack of employment means high poverty risk, which again accelerates migration from the rural areas. All these processes undermine the possibilities for local development simply because there is not enough human or economic capital to sustain rural development. These negative trends are not only typical for rural areas of Russia but have a strong impact on peripheral areas of many other post-socialist and European countries. The governments in Russia and European Union introduced various programs and measures to promote local development so that to overcome the negative consequences of all the mentioned vicious circles. In the first part of the article, the authors evaluate some local development efforts funded by the Ladoga Initiative project, successful and failed projects aimed at overcoming the vicious circles. In the second part of the article, the authors describe grant and priority programs introduced in Russia to support local development.
\end{abstract}

Key words: local development; local initiatives; Lake Ladoga Region; rural periphery; successful projects; failed projects; funding

The fruits of the Russian economic growth have not trickled down to Karelia or her rural areas: the gross regional product (GRP) in the Republic of Karelia does not exceed $80 \%$ of the national average [6]. In general, the Republic of Karelia is classified as a region without a clear specialization, which means that no economic sector performs here above the national average. The only sector approaching the national average is 'non-marketed-services' or public sector. Karelia is usually considered a 'remote periphery' in the regional system of North-Western Russia [15; 20]. It is geographically remote from the core economic areas (like Saint Petersburg) and suffers from many

* (C) J. Nikula, Inna Kopoteva, 2020.

The article was submitted on 06.05.2019. The article was accepted on 03.09.2019. 
such problems as depopulation, weak economic activity, budget deficit, low investment potential, poverty and social differentiation, insufficient urbanization and insufficient infrastructure $[2 ; 9 ; 10]$.

In recent decades, the role of the Ladoga Region has not been very significant in the Karelian economy for its economic potential depends mainly on tourism. In recent years, the infrastructure servicing tourism has developed due to investments in roads and tourist attractions. However, it is the public sector that provides employment for the majority of rural population. The economy of Karelia deteriorated in the last $3-4$ years, and the region accumulated debts; therefore, Karelia has recently asked for emergency financial help from Moscow due to being unable to fulfill some of its key budgetary obligations [24]. The Karelian economy is very vulnerable and the local governments do not have resources for development policies, because they depend on federal and regional funding. In general, the situation in the Karelian countryside is not any better than five years - its development is too slow.

One of the approaches to revitalizing the Karelian economy is initiative projects. One of the most famous is the Ladoga Initiative project implemented in 2011-2013. The project aimed at the transfer of successful practices and knowledge on the local development from Finland to the selected areas in Karelia and Leningrad Region. Such practices and principles include a definition of the village is a basic unit of rural development; organizing local action groups as a link between local population and local authorities; accepting the experiences and understanding of local people as an important means of the development efforts [12; 13]. Ladoga Initiative also emphasized the central role of local actors in developing the strategy and selecting the priorities, which meant that partnerships between population, administration and local businesses were to be promoted. Several mini-projects finished in summer of 2013 after the official end of the project that was considered successful in achieving its main goals, supporting local cooperation initiatives, and teaching project skills to local activists [13].

Five years later after the Ladoga Initiative, we made a post-evaluation trip to Russian Karelia in order to answer the following questions: How were local people pushed to activism and how were local projects implemented? How the maintenance of the projects results was organized? Who was responsible for it and what was done during five years after the project? Activating people and developing partnership relations are very long processes that worked within the project, but did they continue to develop after the end of the Ladoga Initiative project? Are the local action groups still working and do people continue to work for the community? Do the partnership relations established within the project still work? What is the general situation with civic activity in the Russian rural areas? Is there any significant social capital in rural Russia?

Another important task of the research was to find out if the Ladoga Initiative project could contribute to adapting the LEADER approach in Russia [12-14]. Although the scope of the problem in the West and Russia is different, the challenges the rural areas face are quite similar: basically, how to keep a viable countryside by providing jobs and ensuring a satisfactory quality of life. Therefore, implementation of the LEADER approach is not only possible but also highly desirable for rural development. This, another main question of the research was about the barriers and challenges for adapting the LEADER project in Russia? 
We conducted our evaluation research in September 2018 in the selected locations in the Olonets and Pitkaranta municipal districts of the Republic of Karelia. We chose these two municipal districts as our case because they had the largest number of projects funded within the Ladoga Initiative (25 out of 30 ).

\section{Successful projects}

The original idea of the Family Centre "Rodnik" was to create a cultural place for recreations. The activists used project funding to buy furniture and gym equipment and used their own resources to repair the building. The work was done with the help of a group of volunteers, two local enterprises and the local authorities. The main activist was an employee of the local cultural house. Today "Rodnik" has a library room, the main hall, a gym, and an outside performance platform used mainly in summer. During five years after the Ladoga Initiative, the rooms were redecorated, but the weaving loom was taken away and its room is used as a dressing room and wardrobe for concerts. The main hall is used for different local events, elections and can be rented for family events like birthdays (the rent is paid to the local budget).

The main hall is used almost on daily basis. About $10 \%$ use the gym daily for 30 Rubles per hour. There is few equipment in the gym for nothing was bought after the Ladoga Initiative project. A part of equipment needs repairs; since part of the gym was used as a temporary storage for building materials for the neighboring room, another part of equipment was not used. The local administration participated twice in a funding competition in the Karelian Program for Local Initiatives Support so that to get a shower for the gym, but the applications were not chosen for funding.

The library has collections of books and journals but no modern technologies or services (games, Internet, CDs or DVDs). The main users of the library are children and elderly for the youth do not find anything interesting and adults have own computers and TVs. Moreover, the local school has its own library which also reduces the number of users of the 'Rodnik'-library.

'Rodinik' staff plans to have disco and other such activities outside its building, at the performance platform. Local administration organizes village meetings every second, year and the attendance is relatively good. In addition to village meetings, there are other local events that usually attract about $40-50$ people once a month. The building has a room which is under renovation to be transformed into a local post-office. Local authorities occasionally organize courses for the local unemployed (about once in three years) and pay for the maintenance of the 'Rodnik' that employs two persons a librarian and a cultural club manager, and plan to hire also a gym trainer and a handicraft teacher. Besides, there is an idea to resume cooperation between the women's society 'Aino' and the Finnish 'Martta' and to develop interaction with travel agencies.

Thus, the project was partly a success for it managed to create a common place for the locality. The rents and fees do not cover the maintenance costs of the building, and the main responsibility for it is on the local authorities. The project did not partly succeed for it failed to create wide partnerships with local businesses or organisations and turned into an 'administration project', in which the local authorities pay wages and provide money for various purposes. Such a central role of the local administration in the local development contradicts to the key ideas of the LEADER project that aims 
at encouraging local people to create voluntary organisations to innovate, organize and coordinate developmental ideas and cooperate in their realization. In Russia, as a rule the local administration is the key actor for two reasons; first, most of the state programs insist that administrations are the main applicants for funding rather than local people; second, in general it is extremely difficult for local people to create NGO's due to too complicated procedures and too demanding bureaucracy.

Village Läskelä in the Pitkaranta municipal district is an interesting case, because there are active members of local community participating in different projects: a local teacher, a head of municipality, entrepreneurs, school pupils and their parents. Within the Ladoga Initiative project, the local initiative group decided to create a sports ground. According to the plan, a $364 \mathrm{~m}^{2}$ professional jogging artificial track was built around the school's stadium, 70 meters of concrete and 85 meters of wooden border were made together with a runway for long jumps, horizontal bars, wall bars, two basketball stands with shields, and the benches for football players. The main actor of the sport ground project praised the Ladoga Initiative project as a good experience for other projects. The new knowledge in project details allowed the local community to apply for grants from other sources. The school applied to the Timchenko Foundation and to different regional and federal foundations for various grants such as for building an ice-rink and playground for children. The ice-rink and playground for children were also built near the school. There is also a track of the Great Patriotic Game consisting of different barriers to go under or climb over. There is a republican school competition in this 'sports, and the Läskelä school won it three times in a row. All other projects around the school are linked to sports, and there is a plan to build a biathlon track for the summer.

Thus, this case is very successful due to the efforts of a group of active people who managed to implement the project, to develop the project culture among members of the group and to participate in other grant program. Here the Ladoga Initiative project gave an impulse for the active rural development.

In the village Salmi of the Olonets ethnic municipal district, the project aimed at opening a new rural hairdressing salon with modern equipment to use new technologies in hairdressing and to improve the quality of services for the rural population. Two local women studied at the Center for Employment to develop business plans under the state Self-Employment Program. After presenting their business plan they received funding to start their business. The entrepreneurs opened a hairdressing salon by renting and repairing the premise and buying some equipment with their own money and with the Ladoga Initiative funding. From the beginning, the business grew steadily, and they planned to have new services (nails, make-up, etc.) for those 15-18 clients they had a day. Unfortunately, one business partner died a year ago.

In the village, there are two hairdressing salons. There is no competition between them for both have their own clients. The entrepreneurs' hairdressing salon has about 10 clients a day, which is enough for one working person. Owner of the salon does not plan to hire any trainee or co-worker, but she would like to rent another seat for a co-worker with her/his own clients. The entrepreneur still rents the premise from Pitkaranta district municipality and wants to buy it. However, the local authorities do not wish to sell it. The entrepreneur would like to get an additional training so that 
to provide new services, but she is not ready for full-time studying. The entrepreneur is aware that there are programs to apply for funding for renovations, but she does not see any urgent need for that.

This is an example of successful and quite entrepreneurial project that met the goals of the Ladoga Initiative. The good side of this project is that it combined the state funding within the Self-Employment Program and the Ladoga Initiative funding to create and develop additional services for the rural population. It was the only business project supported by the Ladoga Initiative, because the local people refused to fund any business as lacking any socially significant effect. The people preferred to wait for state initiatives to get services free of charge instead of supporting entrepreneurs to provide them. Although creation of new jobs was a priority in all project rural areas, the applications of private businesses providing new jobs were nor supported according to the principle 'we would rather be poor than let others earn money'.

The hairdressing salon was successful probably because it was already working and people got used to it. There was a request from the local population to develop colouring services, for which additional equipment was needed and was bought within the Ladoga Initiative project.

In the village Vidlitsa of the Olonets ethnic municipal district, the main actor of the project 'Names of the Native Region' was a village cultural club with its staff. The idea was to get the rural youth involved in the process of collecting photos and videos of the oldest inhabitants of the village to save their stories, to learn about history and culture, to make an exhibition and to publish leaflets. For this purpose, several courses with journalists and photographers of the local newspaper Olonia were organised for the youth. The cultural club coordinated the creation of electronic photo albums and web pages about the veterans of Vidlitsa, and organized an exhibition in the village. Moreover, some equipment was bought, such as a camera, computer and multifunction device (printer/xerox/scanner). Today the multifunction device is used by the administration, the computer and camera — by the cultural house 'Fiesta'. The cultural house also bought a projector with their own money to organize a mini-cinema for the kids.

The project 'Names of Native Region' continues: Vidlitsa veterans' organization got funding from the Timchenko Foundation to make historical-ecological trails with different objects of historical-cultural heritage in the Vidlitsa rural municipality. The length of the route is about $7-10 \mathrm{~km}$. The project includes several films about the trails and trekking of the local people along the trail to combine the ideas of fitness, local history and environment protection. The first trekking attracted a lot of local people with some walking, some biking. The project was implemented by the non-registered initiative group. The Ladoga Initiative Project taught the local people skills of writing applications and voluntary work, which are the only possibility to get things done. The main obstacle for such work is co-financing of projects which is an obligatory part of any grant program, i.e. it is quite easy to organize voluntary works, but very difficult to find money for co-financing.

Another 'people's project' aimed at creating the monument in honour of those who returned from the World War II. This project was implemented in the village Vidlitsa in 2017-2018 with 270 thousand Roubles. It was planned to have 180 names on the monument, but at the end there were more than 300 . People wanted to see the names 
of their relatives who participated in the World War II. This patriotic project collected a lot of money and many volunteers. Current and former villagers, some living in Moscow, Saint Petersburg and even Finland, participated in the project considered as an important part of their life. Thus, history seems to be a powerful stimulus for people to invest money and engage in voluntary activities for common goals.

Here we see two active actors - the cultural house and the veterans' organization which implement many projects and play a key role in the local development. Beyond efforts of these organisations, there does not seem to be any active partnership of other potential actors like local authorities, business or local people. The local administration supports local initiatives to some extent, but the cultural house operates mostly by itself; while entrepreneurs are not interested to help or participate in any of such activities. Moreover, the demographic structure of Vidlitsa sets some limits to activities too since $60 \%$ of its population are pensioners. There are young and active people among local entrepreneurs and administration, but probably the volatile nature of funding of local development and lack of local financial and other resources do not allow the local entrepreneurs to invest money and efforts to the local developmental.

In the village Iljinsky of the Olonets ethnic municipal district, there is a large group of local craftsmen mainly women. The idea of the project 'Merkki' (in Karelian 'brand') was to create a brand for the local handicraft production. They craftsmen made a logo for the badges and an official emblem for the cultural house. This logo consists of a pine-tree on the banks of the Olonets-river. Today it is used as a badge for carpets and mittens only. To promote the sale of carpets and mittens they invented stories to make customers interested in their goods: "They are special, not a mass product". However, the logo is not registered, which is crucial for any brand.

There are about 30 craftsmen in the village. They have premises in the local cultural house -5 hand looms and 1 for children; besides, there are 8 private hand looms in the village. The craftsmen organize courses for young people and participate in handicraft exhibitions in Karelia. They produce carpets, mittens, various things from birch bark, bed covers, etc. In 2016, 28 craftsmen participated in the large exhibition of the traditional Karelian handicrafts in Petrozavodsk, later in exhibitions in other Karelian towns like Olonets (2017), Belomorsk (2018), etc. 34 craftsmen participated in the celebrations of the Day of the Republic by a 'carpet march'. Their plan to make their products more successful and well-known is hampered by the fact that there are no cheap products. They wanted to create a line of products from the cheapest ones to more expensive, but still did not succeed, which explains why they still do not sell much. Thus, to ensure the sustainability of this successful project, the local craftsmen have to take many additional steps to intensify and improve marketing, to start cooperation with tourism business, to create a group in social networks or a web-site to promote their products through the Internet, etc.

\section{Failed projects}

In 1996-2000, there were almost 40 members in the women handicraft club in the Vidlitsa village. They had contacts with the Finnish women organization 'Martta' and Valmet tractor factory through the local state farm. In the Ladoga Initiative project, 
there were 13 older ladies who weaved carpets with hand looms. The club did not have any legal status, premises or state support, it was and still is an informal club with association as a key goal and communality as a key value. When this group applied for funding from the Ladoga Initiative project, their idea was to organize master classes to contribute to the revival and promotion of the Karelian crafts by providing necessary facilities for leisure and recreation activities. With the project support the premises were repaired, furniture and some equipment were purchased.

Today there are 9 older ladies who gather twice a week to weave and talk. The premises represent a problem for any activity, because it lacks toilet, water and heating. The club rents the premises from the former state farm which is a private enterprise, and the ladies pay for the electricity. The club members are aware of funding possibilities but they do not want to apply, because they know and fear the efforts to prepare all the papers. They receive some financial help from the local shop keeper, but in general manage on their own. They believe that people are scared to make formal organization because of bureaucracy. Moreover, the life in the village has worsened: there are no big enterprises left and the youth leaves the village, because there are no jobs. Since there are no enterprises, there is no income for the local budget and development. The available services in the village include ambulatory (a health center), minibuses to Olonets and big buses to Saint Petersburg. However, the level of living has improved: "in the 1990s, under the economic crisis, people bought only a toothpaste, but now under the economic crisis people buy televisions and freezers".

The women handicraft club still function despite the fact that the number of its members decreased. Within the Ladoga Initiative project, they improved the rented premises, bought a heater and a teapot. Today they organize meetings twice a week, which is very important, but they did not achieve the goals of the project — the transfer of skills and knowledge in weaving, higher incomes for the members of the club, and mutual benefits for the local administration and local business.

In the village Iljinsky, the idea of the Ladoga Fair was to improve collaboration of the three districts' artisans: 3 tents were bough so that artisans and other actors (dancing groups and other cultural activists) could participate in different fairs and markets in the area. The group of artisans rented mini-buses within the Ladoga Initiative funding, and today they also have to rent buses, which limits their participation in different events. They rent a bus from the local enterprise, the former state farm, which is expensive. The local administration does not have its own transport, and the local school does not want to provide its bus. The cooperation of artisans did not develop much after the Ladoga Initiative project, but there are some joint activities (like markets of entrepreneurs from different locations).

In the village Iljinsky, the idea of the Ladoga Wave project was to improve the traditional recreation site on the Ladoga shore. The plan was to establish 'ecological days' to combine cleaning of the lake shore with enhancing the community spirit. The initiators of the project applied for funding for constructing cabins to change clothes and to buy a generator for the equipment. Unfortunately, the part of funding from the local authorities was delayed, the weather conditions did not allow to organize the first event, and the attendance of local people was much smaller than the organizers hoped. 
The project could have been very important for the village development: it was to attract the unemployed to do something meaningful for the community and, thus, to prevent them from social exclusion; and also to develop tourism that would create new jobs. Besides the reasons mentioned above, the project did not succeed for the authorities prohibited all activities at the lake after the accident at the Lake Sjamozero, when a group of young people drowned. Today the project exists rather informally as an active group of families not allowed to organize anything at the Lake Ladoga shores, which means that there is actually no ecological project. This group organizes small ecological actions twice a year to clean the Ladoga Lake's shores.

\section{Local development and grant programs}

The Ladoga Initiative project is one example of the local development mechanisms. LEADER is the European methodology of rural development which we tried to apply to the Russian rural areas within the Ladoga Initiative project. The success of this methodology is possible if all actors involved are interested in it and have resources for its implementation. However, in the Ladoga Initiative project we had problems with the local authorities' financial obligations.

One of the priorities of the Russian municipal reform since 2006 has been fastening the profitable resources and eliminating the non-financed mandates. The effective implementation of local functions depended on the financial and economic resources of municipalities; therefore, changes in the mechanism of financing municipalities were the key aspect of the municipal reform. The Article 49 of the Federal Law FL-131 (2003) 'On the Basic Principles of Local Government in the Russian Federation' defined the term "economic basis of local self-government" as a combination of municipal property, property rights of municipalities and local budgets. However, the implementation of the municipal reform was not supported by other economic measures. The local government can be effective only if it is economically successful, i.e. has a sufficient local budget. For many years political and scientific elites discussed the problem of insufficient budgets, but nothing changed. Under the reform, the dependence of local budgets on the financial support increased. The ability of local budgets to solve local problems depended on the transfer of tax shares and/or direct financial support from the higher levels. Thus, the local self-government was declared independent, but the state did not provide the economic basis for this independence. The local government was deprived of autonomy in financial management, confused by constant changes by the federal authorities, and drown in debts.

The Russian state introduced a number of documents on rural development and means to promote it, in which emphasized the importance of partnerships between the state, local governments, businesses and rural population, and the need to develop local self-government, civil society and all forms of cooperation. The Russian state developed a system of grant support/priority projects to encourage initiatives of rural communities, especially in physical culture and sports, children's and youth recreation, and preservation of environment. Rural development programs are funded by three levels - local, regional and federal; besides, there are also private foundations' projects to support the very limited local budgets. 
Good funding possibilities for the local development are provided by the Program for Supporting Local Initiatives within the State Program 'Development of Civil Society Institutions and Local Self-Government, Protection of Human and Civil Rights and Freedoms' for 2014-2020. This federal program is implemented in many Russian regions including the Republic of Karelia. At first only rural and urban settlements could participate in the program, in 2015 urban districts joined it, and in 2016 municipal districts too. The program aims at the development of social infrastructure of municipalities through the allocation of subsidies from the national budget for the implementation of the most significant projects initiated by the population.

Objectives of the program are different across Russia, but the main ones are the same: support for activity of citizens at the local level, development of mechanisms of interaction between the authorities and population, increasing the level of public confidence in the government, improving the efficiency of budget expenditures and the social well-being of local residents (sports facilities, playgrounds, cultural and educational institutions, water supply systems, fire piers, municipal roads, parks, reconstruction of monuments and memorial complexes, etc.). One example of such projects is the construction of outdoor fitness facilities in rural villages. For instance, in Vidlitsa outdoor fitness facilities were built near the local administration together with a small park. The head of the local administration also received funding for cleaning parks. Both projects are examples of creating environments that are more comfortable and enlarge common public spaces for local people. Most such projects focus on building children playgrounds and sport facilities, repairing cultural institutions, general improvement of the territories and repairing water supply systems.

As many other grant programs, this program also is based on the principle of co-financing. Its budget consists of the sources from the budget of the Republic of Karelia, municipal budgets and individuals and legal entities. The share of municipal sources is $30 \%$ for urban districts, $20 \%$ for municipal districts and urban settlements, and $10 \%$ for rural settlements. The sources of local population and other legal entities is $10 \%$ for urban districts and 5\% for municipal districts, urban and rural settlements.

In the first four years of the program 172 project were implemented through 6 steps. First, a group of active people - a local initiative group - has to be created to discuss the most important problems of the territory (if needed, a small local survey can be conducted). Then there has to be a village meeting so that the local people discuss village problems and select one of them for the program. At the next step the application is written by the active locals together with the local authorities. The chosen projects are announced, and the two last stages are implementation of the project and writing a report on it. The role of the local initiative group is very important for it is responsible for application, collection of funds from the public and sponsors, informing the public about the progress of the project, monitoring the quality of work and ensuring the safety of the object in the future.

The overhaul of multi-store houses is a serious problem in Russia - more than $75 \%$ of apartment buildings have served for more than 25 years and need overhaul to restore proper technical condition. According to the Civil and Housing Codes of the 
Russian Federation, the costs of properly maintenance of multi-store houses including repairs are to be borne by their owners. In 2013, the highest executive authorities of the Russian regions introduced regional programs for the overhaul of multi-store buildings: the owners of premises began to form a fund for the overhaul by monthly contributions for major repairs. Besides, there would be subsidies from the state if the region adopted a regional program (state subsidies can cover up to $50 \%$ of total costs, but no more than 5 million Roubles). There is a list of works that can be done within this program: repair of in-house engineering systems like electricity, heat, gas, water supply, drainage; repairs or replacement of elevator equipment; repairs of elevator shafts, roofs, basements, facades and the house foundation.

In our research, 69 multi-store houses in he Läskelä rural municipality participated in the program to repair the foundation of the building, its roof, including rebuilding a non-ventilated roof into a ventilated one, to construct an access to the roof, to repair the facade, power and heat engineering systems, cold- and hot-water supply systems inside the house and basements, etc. Houses that were not included in the program make up a reserve list. However, no more than $10 \%$ of the total costs of the program can be used for the reserve list, which in fact means that no more houses can be added to the program. In general, there are more than 6500 houses in Karelia in the program.

Another state program aims at resettlement from dilapidated and collapsing housing and providing the population with housing of good quality, which does not pose a threat to life and health. Initially, it was to provide people with new housing in 8 years $(2002$ 2010), but the authorities did not manage to achieve the goals of the program. Thus, it was extended to 2017 , but additional 7 years did not bring the desired result, so it is to be completed in 2020. In our case study, only the Läskelä administration tried to participate in all possible programs including the dilapidated housing program: people from 51 apartments of the 12 dilapidated multi-store houses got new apartments.

The federal priority project 'Comfortable Urban Environment" was approved in 2016 to ensure in 2017-2022 the annual implementation of a set of priority activities aimed at the systematic improvement of the quality and comfort of the urban environment at the municipal level (in municipalities with more than 1000 inhabitants). To implement such activities in the Republic of Karelia in 2018, more than 139 million Roubles were allocated - 94\% from the federal budget and 6\% from the budget of the Republic of Karelia. In 2018, 52 settlements participated in the project. Subsidies to the municipalities were distributed on the basis of the level of budget provision of municipalities and the number of population. The basic list of approved works consisted of repairs of driveways, lighting the yard areas, installation of benches and litter bins; while the additional list included building sidewalks and footpaths, installation of curbstones and swings, enlarging children's (playing) and sports grounds, landscaping the territory, installation of lawn and decorative fences, dismantling of outbuildings, construction of sheds, etc. Works from the additional list requires co-financing from the local population or other local actors (not less than $3 \%$ of the budget of the Republic of Karelia allocated for additional types of works).

To become a part of the federal priority project it is necessary to meet two criteria: the meeting of the local population has to be organised and an application has to be 
made. At the meetings the local people have to make proposals on what to improve, what works to be done, which is a problem for the local people are not active. Besides, there are conflicting interests: playgrounds are a priority for young couples with children, gym and other sport equipment - for the youth and working-age population, benches, landscaping, etc. - for the elderly. Within the priority project 'Comfortable Urban Environment', in Läskelä the Pushkin park was improved together with the yards of multi-store houses including repairs of outdoor toilets and woodsheds, asphalting yards and some children playgrounds.

Another important program of the Russian Federation is 'Assistance to Starting Entrepreneurs', according to which the employment centers provide citizens with financial assistance in opening their business. In 2019, the state allocated one-time subsidy of about 60 thousand Roubles for opening a business. The sum is small, but the conditions are easy: no competitive selection, not very strict requirements to a business plan (innovation, profitability, employee recruitment, availability of own starting capital and the use of the subsidy). According to the statistics, only $2 \%$ of the unemployed apply for such subsidies In the Ladoga Initiative, there was only one business project for the local population is not ready to support business projects. All state programs for the local development works through the local authorities, which means that the local actors cannot apply for funding - only registered organizations can. However, there is private funding options, for instance provided by the Timchenko Foundation, that allow the local people to apply for funding directly.

Although the years of economic growth have not brought much prosperity to the rural areas of Russian Karelia, the living environment has improved. The successful projects that started under the Ladoga Initiative and within different funding schemes prove once again that the level of activity and commitment of local actors destroy the general beliefs of passive and consumer collective mentality of the rural population. As a rule, successful projects are those that have enthusiastic actors willing to further promote their ideas and activities, working hard and supported by the local authorities with the same priorities (sports, historical memory, etc.).

The other side of the coin is that some of the goals within the Ladoga Initiative project presuppose that the key local development actor is mainly the local authorities that participate in the competition for funds and take responsibility for implementing projects, while the local people are to suggest ideas and work as volunteers. In principle, there is nothing wrong for such a model creates a basis for the common interests of the local authorities and population and makes the application for funding somewhat easier. However, the main problem is that the projects gradually turn into only a source for funding for the local authorities; thus, there is no guarantee for having projects crucially important for the local community. Today the local development projects are mainly coordinated 'from above' — through various programs and funding schemes. The local actors refuse to register associations or NGOs due to the fear of bureaucratic load, responsibilities for running a project or a new organization, and the general social atmosphere that is not in favor of informal organizations (civil society and all other forms of cooperation). 


\section{References}

[1] Barsukova S.Yu. Essay on the Informal Economy, or 16 Shades of Gray. Moscow; 2015 (In Russ.).

[2] Between House... and House. Return Spatial Mobility of the Russian Population. T.G. Nefedova, K.V. Averkieva, A.G. Makhrova (Eds.). Moscow; 2016 (In Russ.).

[3] Bowles S. Moral Economy. Why Good Incentives Are No Substitute for Good Citizens. Moscow; 2017 (In Russ.).

[4] Bozhkov O.B., Trotsuk I.V. Tendencies of the Russian rural areas development: The research task and first results of the comparative case-study. RUDN Journal of Sociology. 2018; 18 (4) (In Russ.).

[5] Ellickson R. Order without Law: How Neighbors Settle Disputes. Moscow; 2017 (In Russ.).

[6] Kolesnikov N., Tolstoguzov O. Structural changes in the economy of the Russian Northwest: spatial dimension. Baltic Region. 2016; 2.

[7] Kumpulainen K. Village Action and the Production of an Active Village. University of Jyväskylä; 2012.

[8] Lindner P., Moser E. (De)centralization of rural Russia: Local self-government and the 'vertical of power'. Peasant Studies: Theory. History. The Present. Moscow; 2011 (In Russ.).

[9] Meanings of Rural Life (A Sociological Analysis). Zh.T. Toshchenko (Ed.). Moscow; 2016 (In Russ.).

[10] Multi-forms of the Russian Ways of Life: Historical Roots, State, and Prospects. T.E. Kuznetsova (Ed.). Moscow; 2009 (In Russ.).

[11] Nefedova T.G. Ten Actual Questions about Rural Russia: Answers of a Geographer. Moscow; 2013 (In Russ.).

[12] Nikula J., Granberg L., Kopoteva I. LEADER and possibilities of local development in the Russian countryside. L. Granberg, K. Andersson, I. Kóvach (Eds.). Evaluating the European Approach to Rural Development: Grass-Roots Experiences of the LEADER Program. Ashgate; 2015.

[13] Nikula J., Kopoteva I. From social innovation to innovation system: LEADER in European and Russian rural areas. Mir Rossii. 2014; 23 (3) (In Russ.).

[14] Nikulin A.M., Trotsuk I.V. Rural development of Finland: The interaction between state, farmers and scientific knowledge (possible lessons for Russia). Mir Rossii. 2014; 3 (In Russ.).

[15] Pilyasov A.N. And the Last Will be the First: The Northern Periphery on the Way to Knowledge Economy. Moscow; 2009 (In Russ.).

[16] Scott J.C. Weapons of the Weak: Everyday Forms of Peasant Resistance. Yale University Press; 1985.

[17] Spatial Potential in the Strategy of Social-Economic Development of Russia. Moscow; 2011 (In Russ.).

[18] The Postsocialist Agrarian Question. Property Relations and the Rural Condition. Hann C., Rottenburg R., Schnepel B., Shimada S. (Eds.) Vol. 1. Lit Verlag; 2003.

[19] Trotsuk I.V. A guide to the post-soviet agrarian reform in Russia: Objective and subjective dimensions of rural life. Russian Peasant Studies. 2017; 2 (3) (In Russ.).

[20] Trotsuk I.V. Encyclopedia of life of the Russian northern periphery, or Recipes to heal the one not doomed to poverty. Peasant Studies: Theory. History. The Present. Moscow; 2014 (In Russ.).

[21] Uusitalo E. Finnish rural policy and local initiatives. Finnish Journal of Rural Research and Policy. 1999; 2.

[22] Uzun V.Ya, Shagaida N.I. Agrarian Reform in Post-Soviet Russia: Mechanisms and Results. Moscow; 2015 (In Russ.).

[23] Wegren S., Nikulin A., Trotsuk I. Russian agriculture during Putin's fourth term: A SWOT analysis. Post-Communist Economies. 2019; 31 (4).

[24] Zubarevich N. Regional and social aspects of the Russia's crisis. $16^{\text {th }}$ Aleksanteri Conference "Life and Death in Russia". University of Helsinki; 2016. 


\title{
Проекты местного развития в Приладожье: причины успешности и подходы к финансированию*
}

\author{
Й. Никула ${ }^{1}$, И. Копотева ${ }^{1,2}$ \\ ${ }^{1}$ Университет Хельсинки \\ Юнионинкату, 33, Хельсинки, 00014, Финляндия \\ ${ }^{2}$ Российская академия народного хозяйства и государственной службы \\ при Президенте Российской Федерации \\ Просп. Вернадского, 82, Москва, 119571, Россия \\ (e-mail: jouko.nikula@helsinki.fi; inna.kopoteva@gmail.com)
}

Периферийные (сельские) регионы большинства стран мира сталкиваются с четырьмя замкнутыми кругами проблем, которые являются причиной их низкого уровня развития и неспособности достичь устойчивых социально-экономических показателей. Первый круг проблем связан с демографическими особенностями сельских районов: незначительная доля молодежи и гендерный дисбаланс снижают экономические показатели, что приводит к доминированию натурального хозяйства над производством и торговлей; смещенная возрастная структура в сочетании с низким уровнем услуг определяет низкую рождаемость и высокий миграционный отток. Второй круг проблем - пространственной изоляции - объясняет неразвитую инфраструктуру, которая не привлекает бизнес и новых жителей, но выталкивает молодежь и трудоспособное население, особенно семьи с маленькими детьми. Третий круг проблем связан с образовательными возможностями: низкий уровень образования и навыков означает, что в сельских районах не хватает рабочей силы, что также не привлекает сюда бизнес. Высокая безработица влечет за собой высокие риски бедности, которые усиливают миграционный отток из сельских районов. Все эти круги проблем препятствуют местному развитию просто потому, что на сельских территориях недостаточно человеческого и экономического капитала. Такие негативные тенденции характерны не только для сельских районов России, но и оказывают серьезное влияние на периферию многих постсоциалистических и европейских стран. Правительства стран ЕС и России реализуют множество программ в целях местного развития, чтобы преодолеть негативные последствия обозначенных кругов проблем. В первой части статьи авторы оценивают возможности их преодоления в рамках проекта «Ладожская инициатива» (успешные и неуспешные усилия по решению местных проблем). Во второй части статьи авторы описывают ряд российских грантовых и приоритетных программ, призванных способствовать местному развитию.

Ключевые слова: местное развитие; местные инициативы; Приладожье; сельская периферия; успешные проекты; неуспешные проекты; финансирование

* с С Никула Й., Копотева И., 2020.

Статья поступила 06.05.2019 г. Статья принята к публикаџии 03.09.2019 2. 